CESIS Electronic Working Paper Series

Paper No. 370

\title{
A note on firm age and the margins of exports: First evidence from Germany
}

\author{
Joachim Wagner
}

July, 2014 


\title{
A note on firm age and the margins of exports:
}

\section{First evidence from Germany}

\author{
Joachim Wagner \\ Leuphana University Lueneburg, Germany, and CESIS, KTH Stockholm, Sweden
}

[This version: July 17, 2014]

\begin{abstract}
This note uses a new tailor-made data set to investigate the link between firm age and the extensive and intensive margins of exports empirically for the first time for Germany. Results turn out to be fully in line with the theoretical considerations. Older firms are more often exporters, export more and more different goods to more different destination countries, and export to more distant destination markets.
\end{abstract}

Keywords: Exports, firm age, export margins, Germany JEL Classification: F14

\footnotetext{
All computations were done at the Research Data Centre of the Statistical Office of BerlinBrandenburg in Berlin. The firm-level data used are strictly confidential but not exclusive; see http://www.forschungsdatenzentrum.de/datenzugang.asp for information on how to access the data. To facilitate replications the Stata do-file used is available from the author on request.
}

Prof. Dr. Joachim Wagner

Leuphana University Lueneburg

Institute of Economics

PO Box 2440

D-21314 Lueneburg, Germany

e-mail: wagner@leuphana.de

www: http://www.leuphana.de/joachim-wagner.html 


\section{Motivation}

Empirical models for the export participation of firms, or for the share of exports in total sales of firms, usually include variables that measure a large number of firm characteristics, e.g., firm size, human capital, fixed capital, technology, research and development spending, innovations, patents, characteristics of the work force, foreign ownership, branch-plant status, number of products, and industry affiliation. One firm characteristic that is missing in nearly all of these models is firm age, and this holds for more recent empirical models that look at extensive margins of exports (number of goods exported, number of countries traded with), too.

Germany, one of the leading actors on the world market for goods, ${ }^{1}$ is a case in point. Wagner (2011) summarizes 51 empirical studies published between 1991 and 2011 that use micro-data for German firms to investigate the determinants of exports. The role of firm age is only touched upon in one of these papers (see Wagner 1996).

This neglect of the role of firm age in empirical models of firms' exports comes as a surprise because we can expect that firm age and the margins of export tend to be closely related. David Audretsch (1998, p. 137) points out that "firms are typically created as an experiment to pursue a new idea. If that idea succeeds the firm will tend to grow and create jobs. If that idea is not viable the firm will tend to stagnate and ultimately exit." Although some of these new firms are "born global" firms that head for international markets from the start, typically it takes years before firms eventually export to one foreign market, and then enter other markets progressively.

\footnotetext{
${ }^{1}$ According to the World Trade Organization's World Trade Report 2012 Germany hold rank 3 among the exporters of goods in 2011 with a share of 8.1 percent; see World Trade Organization (2012, p.30).
} 
Firms gain expertise in entering new foreign markets from experience and this lowers the fixed costs of entry to any further new market over the next years (see Sheard 2014, p. 536). A similar argument can be made with regard to the number of products exported. If a firm successfully exported one good and learned how to adopt it to the wants of customers or the legal regulations in a foreign market, how to prepare a user manual in a foreign language, how to set up a distribution network etc., this lowers the fixed costs of exporting any other goods, and the firm will start to export more goods in the years to come. Often firms will start to export to a foreign country that is close to their home country and that has low distance costs (including language barriers, differences in legal systems, or cultural differences), and export to more and more distant destinations after several years of experience only.

At any point in time, therefore, firm age and the margins of exports can be expected to be closely linked. The probability of exporting, the share of exports in total sales, the number of destination countries and the number of goods exported will be higher for older firms. Furthermore, older firms can be expected to export to more distant markets, too.

This note uses a new tailor-made data set to investigate the link between firm age and the extensive and intensive margins of exports empirically for the first time for Germany. Results turn out to be fully in line with the theoretical considerations. Older firms are more often exporters, export more and more different goods to more different destination countries, and export to more distant destination markets.

The rest of the paper is organized as follows. Section 2 discusses the data and measurement issues. Section 3 presents the results of the empirical investigation. Section 4 concludes. 


\section{Data and measurement issues}

The lack of empirical studies for Germany on the link between firm age and the margins of exports is due to the fact that until most recently suitable data at the level of the firm that could be used in an econometric investigation were not available. The empirical investigation here uses a tailor-made data set that combines for the first time high quality firm-level data from two official sources with data on the distance between Germany and destination countries of exports.

Information on the goods traded internationally is available from the statistic on foreign trade (Außenhandelsstatistik). This statistic is based on two sources. One source is the reports by German firms on transactions with firms from countries that are members of the European Union (EU); these reports are used to compile the socalled Intrahandelsstatistik on intra-EU trade. The other source is transaction-level data collected by the customs on trade with countries outside the EU (the so-called Extrahandelsstatistik). ${ }^{2}$ Data in the statistic of foreign trade are transaction-level data, i.e. they relate to one transaction of a German firm with a firm located outside Germany at a time.

For the reporting years 2009 and 2010 these transaction-level data have been aggregated at the level of the exporting firm for the first time. Using the firms' registration number for turnover tax statistics these data were matched with the enterprise register system (Unternehmensregister-System) and with the enterprise level data from the two other sources discussed above. For each exporting firm that reported either to the statistic on intra-EU trade, or to the statistic on trade with

\footnotetext{
${ }^{2}$ Note that firms with a value of exports to EU-countries that does not exceed 400,000 Euro in 2009 do not have to report to the statistic on intra-EU trade. For trade with firms from non-member countries all transactions that exceed 1,000 Euro are registered. For details see Statistisches Bundesamt, Qualitätsbericht Außenhandel, Januar 2011.
} 
countries outside the EU, we know from the data the number of goods exported and the number of countries exported to. Furthermore, this data has information about the ten most important destination countries of exports and the value of exports to these countries. This information is used to construct two indices related to the characteristics of these destination countries. Combined with information on the distance between Germany and each of the destination countries it is used to compute an index of the distance of exports of a firm. Linked to information on the extent of barriers to trade with these countries it is used to compute an index that is a proxy for the difficulty to serve the export markets of a firm. Details on the construction of these two indices are given below.

The second source of firm level information is the regular survey of establishments from manufacturing industries by the Statistical Offices of the German federal states. The survey covers all establishments from manufacturing industries that employ at least twenty persons in the local production unit or in the company that owns the unit. Participation of firms in the survey is mandated in official statistics (see Malchin and Voshage (2009) for details). For this study establishment data were aggregated to the enterprise level to match the unit of observation in the other data sources (described below). From this survey information is used on the age of a firm, its total amount of exports, and its detailed industry affiliation.

Data on distance between Germany and the destination countries of exports are taken from the CEPII's GeoDist database (Mayer and Zignago 2011). The "distw" measure is used that calculates the distance between two countries based on bilateral distances between the biggest cities of those two countries, those inter-city distances being weighted by the share of the city in the overall country's population (see Mayer and Zignango (2011, p. 11) for details). 
With these data it is possible to investigate the relationship between the age of a firm, the extensive and intensive margins of the firm's exports, and characteristics of the destination countries of a firms export.

Information on the age of a firm is not included in the data used here. However, it is possible to distinguish firms that existed already in 1995 (the first year covered by the survey from official statistics) and firms that entered the data set in later years. Using this information three age cohorts of firms are identified. Cohort 1 is made of all firms that existed already in 1995. Cohort 2 includes all firms that entered the data set between 1996 and 2002. Cohort 3 covers all firms that entered the data set between 2003 and 2009. Note that this definition of age cohorts might be fuzzy because a firm that entered the data set in, say, 2003 has not necessarily been founded in 2003 - it might be the case that the firm existed for some years before but that the number of employees was below the threshold value of 20 and, therefore, the firm was not obliged to report to the survey.

The three extensive margins of exports by a firm in 2010 are measured by an exporter dummy variable that takes on the value 1 if the firm was an exporter (and the value 0 otherwise), by the number of goods ${ }^{3}$ exported, and by the number of destination countries of exports. The intensive margin of exports is measured by the share of exports in total sales of a firm.

Distance to export destination is measured by the distw-index between Germany and the destination country provided in the CEPII database (that is discussed above). For firms that exported to more than one country distance is computed as the weighted sum of the distance to (up to ten) destination countries,

\footnotetext{
${ }^{3} \mathrm{~A}$ good is an eight-digit number from the official numenclature for the statistics of foreign trade.
} 
and the weights are the shares of the value of exports to a country in the total exports of the firm to these (up to ten) countries.

Furthermore, a complete set of 4-digit level industry dummy variables is included to control for the role of industry-specific factors.

Given that the East German economy still differs in many respects from the West German economy, especially with regard to exporting (see Wagner (2008)), and that the number of exporting firms is small in East Germany this study looks at West German manufacturing enterprises only.

\section{Results}

The empirical investigation uses information on 29,459 enterprises from manufacturing industries in West Germany in 2010. About half of these firms existed already in 1995 and form cohort 1. Cohort 2 (made of firms that entered the sample between 1996 and 2002) and cohort 3 (including firms that entered between 2003 and 2009) are approximately of same size and cover a quarter of all firms each. Table 1 shows that the share of exporters is larger in cohort 1 compared to the younger cohorts, while the share of exporters is the same in cohort 2 and cohort 3.

[Table 1 near here]

Results for empirical models that test for differences in the intensive and extensive margins of exports between firms from the three age cohorts are reported in Table 2. Note that these models are not used to empirically explain a margin, they are just vehicles to estimate the margin premium of a cohort (controlling for detailed industry affiliation by a complete set of 4-digit industry dummy variables). 
The results for model 1 clearly indicate that the probability of participation in exports (the first extensive margin) is lower in both cohort 2 and cohort 3 compared to cohort 1 (the reference category in all empirical models). The estimated average marginal effect for firms from cohort 1 and cohort 2 is -9.6 percent and -10.4 percent, respectively, and of the same order of magnitude.

These differences are present at the intensive margin of exports (measured by the share of exports in total sales of a firm), too. On average, and controlling for industry affiliation, compared to the "old" firms from cohort 1 the export to sales ratio is 19.2 percent smaller in cohort 2 and 20.2 percent smaller in cohort $3 .{ }^{4}$ Again, both estimated margin premia of cohort 2 and cohort 3 are of the same order of magnitude.

Results for model 3 show that the number of exported goods (the second extensive margin) tends to increase with firm age. Compared to firms from cohort 1 , firms from cohort 2 export 9.5 percent less different goods, and the difference for firms from cohort 3 is 25.5 percent. Results for the number of destination countries (the third extensive margin) show a similar picture. Compared to firms from cohort 1 , firms from cohort 2 export to 20 percent less destination countries, and the difference for firms from cohort 3 is 39.9 percent.

[Table 2 near here]

The results discussed so far consider differences in the means of the margins of exports between age cohorts of firms (conditional on industry affiliation). This might

\footnotetext{
${ }^{4}$ The percentage difference between the cohorts are computed from the estimated regression coefficient $B$ of the dummy variable in the semi-log empirical model by the formula $\left(e^{B}-1\right)^{*} 100$.
} 
not tell the whole story because firms are highly heterogeneous within the age cohorts, too. An empirical study of heterogeneous firms should look at differences in the whole distribution of the variable under investigation between groups of firms, not only at differences at the mean. The empirical strategy used here, therefore, applies a non-parametric test for first order stochastic dominance of one distribution over another that was introduced into the empirical literature on international trade activities of firms by Delgado et al. (2002). Let F and $G$ denote the cumulative distribution functions of an export margin for two age cohorts of firms. Fist order stochastic dominance of $F$ relative to $G$ is given if $F(z)-G(z)$ is less or equal zero for all z with strict inequality for some z. Given two independent random samples of firms from each group, the hypothesis that $F$ is to the right of $G$ can be tested by the Kolmogorov-Smirnov test based on the empirical distribution functions for $F$ and $G$ in the samples. Note that this tests not only for differences in the mean value of the margin of both groups but for differences in all moments of the distribution.

Results for pair-wise Kolmogorov-Smirnov tests for the three age cohorts of firms and for the extensive margin and the second and third intensive margin (i.e., the number of goods exported and the number of destination countries) are reported in Table 3. Note that all values of the margins are expressed as percentage values of the 4-digit industry mean value to control for detailed industry affiliation of the enterprises. Results are fully in line with the conclusions based on the results from the regression models in Table 2. The distribution of the share of exports in total sales for cohort 1 dominates both distributions of cohorts 2 and 3 , while there is no difference between cohorts 2 and 3 . For the number of goods exported and the number of destination countries we find evidence for a clear hierarchy. Each 
distribution for a younger cohort is dominated by the distribution for the older cohort. Both extensive margins increase with firm age.

[Table 3 near here]

As the next step we look at results for an empirical model that tests for differences in the distance to destination countries of exports between firms from the three age cohorts. To repeat, the model is not used to empirically explain this distance, it is just a vehicle to estimate the margin premium of a cohort (controlling for detailed industry affiliation by a complete set of 4-digit industry dummy variables).

Results reported in Table 4 show that the distance to destination countries is larger for firms from cohort 1 than for firms from the younger cohorts. The difference compared to firms from cohort 1 is -9.9 percent for firms from cohort 2 and -7.5 percent for firms from cohort 3.

[Table 4 near here]

Results for pair-wise Kolmogorov-Smirnov tests for the three age cohorts of firms and for the distance to destination countries are reported in Table 5. Values of the distance to destination countries of the firms are expressed as percentage values of the 4-digit industry mean value to control for detailed industry affiliation of the enterprises. Results are in line with the conclusions based on the results from the regression model in Table 4. The distribution of the distance to destination countries for cohort 1 dominates both distributions of cohorts 2 and 3 , while there is no difference between cohorts 2 and 3 . 
[Table 5 near here]

\section{Discussion}

The empirical investigation demonstrate that, controlling for detailed industry affiliation, the export participation and the share of exports in total sales are both larger in old firms from cohort 1 than in younger firms from cohort 2 and cohort 3 , while there are no differences in these export margins between firms from the two younger cohorts. Both the number of goods exported and the number of destination countries tend to increase with firm age. Furthermore, the weighted average distance to destination countries is larger for firms from cohort 1 than for firms from the younger cohorts.

These results are in line with theoretical considerations. Furthermore, a positive link between firm age and export revenue, number of destination countries, and number of products exported has also been found by Bastos and Dias (2013) in an empirical investigation using Portuguese data. Future empirical research on the determinants of the margins of exports, therefore, should investigate these links further, ideally using longitudinal data that cover a large time span (and that are not yet available for Germany, unfortunately).

\section{References}

Audretsch, David B. (1998), New Firms and Creating Employment. In: John T. Addison and Paul J. J. Welfens (Eds.), Labour Markets and Social Security. Berlin etc.: Springer, 129-165.

Bastos, Paulo and Daniel A. Dias (2013), The life cycle of exporting firms. Draft, December. 
Delgado, Miguel A., Jose C. Farinas and Sonia. Ruano (2002), Firm productivity and export markets: a non-parametric approach. Journal on International Economics 57 (2), 397-422.

Malchin, Anja and Ramona Voshage (2009), Official Firm Data for Germany. Schmollers Jahrbuch / Journal of Applied Social Science Studies 129 (3), 501513.

Mayer, Thierry and Soledad Zignago (2011), Notes on CEPIl's distance measures: The GeoDist database. CEPII Document de Travail No 2011-25, December.

Sheard, Nicholas (2014), Learning to Export and the Timing of Entry to Export Markets. Review of International Economics 22 (3), 536-560.

Wagner, Joachim (2006), Export Performance, Human Capital, and Product Innovation in Germany: A Micro View. Jahrbuch für Wirtschaftswissenschaften / Review of Economics 47 (1), 40-45.

Wagner, Joachim (2008), A note why more West than East German firms export. International Economics and Economic Policy 5 (4), 363-370.

Wagner, Joachim (2011), Exports and Firm Characteristics in Germany: A Survey of Empirical Studies (1991 to 2011). Applied Economics Quarterly 57 (2), 145160.

World Trade Organization (2012), World Trade Report 2012. Geneva: WTO Publications. 
Table 1: Firm Age and Export Participation: Descriptive Statistics

Cohort Description Number of firms $\quad$ Share of exporters in 2010

1

Firm existed in 1995

15,232

79.52

2

Firm entered between

6,892

65.74

1996 and 2002

3

Firm entered between

7,335

65.06

2003 and 2009 


\begin{tabular}{|c|c|c|c|c|c|}
\hline Model & & 1 & 2 & 3 & 4 \\
\hline Endogenous variable & & $\begin{array}{l}\text { Exporter } \\
\text { (Dummy; } \\
1=\text { yes) }\end{array}$ & $\begin{array}{l}\text { Log of } \\
\text { share of } \\
\text { exports in } \\
\text { total sales }\end{array}$ & $\begin{array}{l}\text { Log of } \\
\text { number } \\
\text { of goods } \\
\text { exported }\end{array}$ & $\begin{array}{l}\text { Log of number } \\
\text { of destination } \\
\text { countries of } \\
\text { exports }\end{array}$ \\
\hline Method & & Probit & OLS & OLS & OLS \\
\hline $\begin{array}{l}\text { Cohort } 2 \\
\text { (Dummy; } 1 \text { = yes) }\end{array}$ & $\begin{array}{l}B \\
p\end{array}$ & $\begin{array}{l}-0.096 \\
(0.000)\end{array}$ & $\begin{array}{l}-0.1757 \\
(0.000)\end{array}$ & $\begin{array}{l}-0.091 \\
(0.008)\end{array}$ & $\begin{array}{l}-0.183 \\
(0.000)\end{array}$ \\
\hline $\begin{array}{l}\text { Cohort } 3 \\
\text { (Dummy; } 1 \text { = yes) }\end{array}$ & $\begin{array}{l}B \\
p\end{array}$ & $\begin{array}{l}-0.104 \\
(0.000)\end{array}$ & $\begin{array}{l}-0.184 \\
(0.000)\end{array}$ & $\begin{array}{l}-0.227 \\
(0.000)\end{array}$ & $\begin{array}{l}-0.336 \\
(0.000)\end{array}$ \\
\hline Industry controls & & yes & yes & yes & yes \\
\hline Number of firms & & 29,459 & 21,415 & 11,725 & 11,725 \\
\hline
\end{tabular}

Note: For a definition of cohorts see table 1.Firms from cohort 1 are the reference category. The reported results for model 1 are estimated average marginal effects; the prob-values reported are based on robust standard errors. For model 2,3 and $4 \mathrm{~B}$ is the estimated regression coefficient and $p$ is the prob-value based on heteroscedasticity-robust standard errors. Industry controls are dummyvariables for two-digit industries in model 1 and for four-digit industries in model 2, 3 and 4.All models include a constant term. 


\begin{tabular}{|c|c|c|c|}
\hline \multirow[b]{2}{*}{ Hypothesis ( $p$-values) } & \multicolumn{3}{|c|}{ Margins of export } \\
\hline & $\begin{array}{l}\text { Log of } \\
\text { share of } \\
\text { of exports } \\
\text { in total sales }\end{array}$ & $\begin{array}{l}\text { Log of } \\
\text { number } \\
\text { of goods } \\
\text { exported }\end{array}$ & $\begin{array}{l}\text { Log of number } \\
\text { of destination } \\
\text { countries of } \\
\text { exports }\end{array}$ \\
\hline $\begin{array}{l}\text { Smaller values in cohort } 1 \\
\text { compared to cohort } 2\end{array}$ & 0.980 & 1.000 & 0.987 \\
\hline $\begin{array}{l}\text { Smaller values in cohort } 2 \\
\text { compared to cohort } 1\end{array}$ & 0.000 & 0.013 & 0.000 \\
\hline $\begin{array}{l}\text { Distributions differ between } \\
\text { cohort } 1 \text { and cohort } 2\end{array}$ & 0.000 & 0.023 & 0.000 \\
\hline $\begin{array}{l}\text { Smaller values in cohort } 1 \\
\text { compared to cohort } 3\end{array}$ & 0.687 & 0.998 & 0.945 \\
\hline $\begin{array}{l}\text { Smaller values in cohort } 3 \\
\text { compared to cohort } 1\end{array}$ & 0.000 & 0.000 & 0.000 \\
\hline $\begin{array}{l}\text { Distributions differ between } \\
\text { cohort } 1 \text { and cohort } 3\end{array}$ & 0.000 & 0.000 & 0.000 \\
\hline $\begin{array}{l}\text { Smaller values in cohort } 2 \\
\text { compared to cohort } 3\end{array}$ & 0.328 & 0.971 & 0.873 \\
\hline $\begin{array}{l}\text { Smaller values in cohort } 3 \\
\text { compared to cohort } 2\end{array}$ & 0.511 & 0.003 & 0.000 \\
\hline $\begin{array}{l}\text { Distributions differ between } \\
\text { cohort } 2 \text { and cohort } 3\end{array}$ & 0.622 & 0.005 & 0.000 \\
\hline
\end{tabular}

Note: For a definition of cohorts see table 1. All variables are expressed as percentage values of the 4-digit industry mean value to control for industry affiliation of enterprises. 
Table 4: Firm Age and Distance to Destination Countries: Regression Results

$\begin{array}{ll}\text { Endogenous variable } & \begin{array}{l}\text { Log of distance to } \\ \text { destination countries }\end{array} \\ \text { Method } & \text { OLS }\end{array}$

$\begin{array}{lll}\text { Cohort 2 } & \text { B } & -0,094 \\ \text { (Dummy; 1 = yes) } & \text { p } & (0.001) \\ \text { Cohort 3 } & \text { B } & -0.072 \\ \text { (Dummy; 1 = yes) } & \text { p } & (0.012)\end{array}$

Industry controls yes

Number of firms $\quad 11,441$

Note: For a definition of the distance to destination countries see text. For a definition of cohorts see table 1.Firms from cohort 1 are the reference category. $B$ is the estimated regression coefficient and $p$ is the prob-value based on heteroscedasticity-robust standard errors. Industry controls are dummyvariables for four-digit industries. The model includes a constant term. 
Log of distance to

destination countries

Hypothesis ( $p$-values)

Smaller values in cohort 1

0.994

compared to cohort 2

Smaller values in cohort 2

0.004

compared to cohort 1

Distributions differ between

0.007

cohort 1 and cohort 2

Smaller values in cohort 1

0.398

compared to cohort 3

Smaller values in cohort 3

0.001

compared to cohort 1

Distributions differ between

0.002

cohort 1 and cohort 3

Smaller values in cohort 2

0.061

compared to cohort 3

Smaller values in cohort 3

0.513

compared to cohort 2

Distributions differ between

0.114

cohort 2 and cohort 3

Note: For a definition of cohorts see table 1. For a definition of the distance to destination countries see text. Distance to destination countries is expressed as the percentage value of the 4-digit industry mean value to control for industry affiliation of enterprises. 